\title{
Introduktion til Orrin Klapp
}

Dette temanummer af SLAGMARK indledes med to oversatte artikler af den amerikanske sociolog Orrin Edgar Klapp (1915-1997): "Om skabelsen af folkehelte" ("The Creation of Popular Heroes") fra 1948 og "Noter til studiet af skurkeskabelse som en social proces" ("Notes toward the Study of Vilification as a Social Process") fra 1959.

Klapp blev født i Chicago og uddannet på University of Chicago. Da Anden Verdenskrig brød ud, afbrød han sine studier og blev løjtnant i den amerikanske flåde. Efter krigen færdiggjorde han studierne og blev i 1948 ph.d. i sociologi. I 1949 blev han ansat ved San Diego State College i Californien. Her forblev han frem til 1969, hvor han blev udnævnt til professor i sociologi ved University of Western Ontario i Canada. Han forblev tilknyttet dette universitet frem til 1983. Efter i en del år at have lidt af Alzheimers døde Klapp i 1997.

Klapp skrev en række bøger inden for flere forskellige sociologiske områder, bl.a. en indføring $i$ og analyse af socialtype-begrebet (Klapp 1971); en lærebog om sociologi (Klapp 1973); et af de første systematiske forsøg på at sammenkoble informationsteori og sociologi (Klapp 1978) og en sociologisk analyse af kedsomhedens betydning $\mathrm{i}$ informationsalderen (Klapp 1986).

Klaps primære fokus, og udgangspunktet for det meste af hans øvrige forskning, var imidlertid spørgsmålet om, hvorfor og hvordan sociale ritualer, roller og symboler opstår, hvordan de udvikler sig, og hvilken samfundsmæssig funktion de tjener. Et spørgsmål der i særlig grad interesserede Klapp var, hvorfor og hvordan et samfund kategoriserer bestemte individer som helte, andre som skurke og atter andre som narre.

Dette spørgsmål beskæftigede Klapp sig allerede med i sin ph.d.-afhandling (Klapp 1948a), og fra slutningen af 1940erne og op igennem 1950erne publicerede han en række artikler, hvori han analyserede og beskrev heltens, skurkens og narrens sociale ken- 
detegn og funktion (Klapp 1948b; 1949a; 1949b; 1949c; 1954a; 1954b; 1956; 1959). I 1962 sammenfattede Klapp sin forskning på området i bogen Heroes, Villains and Fools. The Changing American Character (Klapp 1962). Og i 1964 udgav han endnu en bog, Symbolic Leaders: Public Dramas and Public Men (Klapp 1964; 2006), hvori han anvendte sine teoretiske grundbegreber til at udvikle en systematisk analyse af, hvorledes offentlige lederskikkelser skabes og etableres.

Klapps overordnede tese var, at helten, skurken og narren udgør tre karakteristiske sociale typer, dvs. generiske kollektive forestillingsfigurer, der i sig sammenfatter og ekspliciterer væsentlige træk ved et givet samfunds normative selvforståelse. Sådanne sociale typer spiller ifølge Klapp en vigtig rolle for samfundets evne til at håndtere og kontrollere individers og gruppers sociale adfærd. Klapps påstand var, at ethvert nogenlunde komplekst samfund har behov for sådanne kollektive forestillingsbilleder, da de udgør en langt mere umiddelbar og effektiv måde at påvirke individers og gruppers følelser, og derigennem styrke den sociale integration og enhed, end mere "rationelle" virkemidler såsom f.eks. offentlig debat og argumentation.

I en artikel fra 1954 identificerer Klapp fire måder, hvorpå sociale typer som f.eks. helte, skurke og narre typisk udfylder denne funktion. For det første repræsenterer disse typer socialt etablerede normative standarder og rollemodeller, som individer kan bruge som målestok til at evaluere og strukturere deres handlinger ud fra. For det andet kan sådanne kollektive forestillingsbilleder hjælpe en gruppe med at organisere, effektivisere og simplificere sin respons overfor og adfærd i forhold til omverdenen, samt fungere som middel til at motivere gruppens medlemmer til handling. For det tredje kan socialt etablerede forestillingsbilleder som f.eks. helte-, skurkeog narreskikkelser tjene til at understøtte og fastholde en gruppes eller et samfunds normative enhed og integration. Endelig mener Klapp, at helte, skurke og narre er symbolske figurer, der altid er udtryk for og indlejret i en tradition, og at sådanne figurer dermed medvirker til at fastholde og videreføre et samfunds overleverede, kollektive værdier, normer og følelser (Klapp 1954a, s. 61-62).

Disse overordnede påstande efterlader dog en række uafklarede spørgsmål. Hvad skal indholdet af sådanne forestillingsbilleder være, for at de kan udfylde disse sociale funktioner? Hvorledes 
opstår de og udvikler sig? Hvordan adskiller forskellige samfunds forestillingsbilleder og sociale typer sig fra hinanden? Og hvordan påvirker nutidens massemedier skabelsen og udbredelsen af sådanne kollektive forestillinger? Det er disse spørgsmål, som Klapp forsøger at besvare, eller i det mindste levere ansatserne af et svar på, i sine artikler.

Klapp hævdede ikke, at han med sin forskning kom i nærheden af at give en fuldstændig og systematisk sociologisk redegørelse hverken af de mange forskellige typer af helte- og skurke-skikkelser, der har eksisteret op i gennem historien, eller af de sociale funktioner som disse sociale typer udfylder. Klapps artikler og analyser har snarere karakter af indledende studier af disse spørgsmål; metodologiske udkast og spekulative (men empirisk funderede) begrebsafklaringer, der skulle rydde vejen for andre forskere og inspirere dem til at videreføre og videreudvikle det arbejde, som Klapp havde påbegyndt.

Dette skete desværre ikke, og Klapps sociologiske studier af helte, skurke og narre er i dag nærmest gået i glemmebogen. Dette er der sikkert mange grunde til. Den mest åbenlyse er dog formodentlig, at Klapp var så uheldig, at hans karriere overlappede med, og i høj grad blev overskygget af, det 20. århundredes uden sammenligning mest kendte og betydningsfulde skikkelse indenfor helte- og skurkeforskningen: Mytologen, kulturhistorikeren og antropologen Joseph Campbell (1904-1987).

Campbells klassiske og indflydelsesrige hovedværk, The Hero with a Thousand Faces (Campbell 1949; 1968), udkom i 1949, året efter at Klapp forsvarede sin ph.d. og fik publiceret sine første artikler. Campbells tilgang til studiet af helte- og skurkeskikkelser var antropologisk og kulturhistorisk. Med udgangspunkt i utallige mytologiske beretninger og antropologiske studier fremsatte Campbell i The Hero with a Thousand Faces sin berømte tese om, at alle helteberetninger deler en fælles grundform: Helten rejser ud; overvinder modgang og vanskeligheder; vinder hæder og ære og vender tilbage fra sit eventyr med gaver og ny erkendelse.

Siden udgivelsen af $A$ Hero with a Thousand Faces har den antropologiske og kulturhistoriske tilgang til studiet af helte- og skurkeopfattelser domineret forskningen på området. Campbells 'monomyte' er blevet det naturlige udgangspunkt for de fleste forskere, 
der beskæftiger sig med disse spørgsmål. Som en naturlig, men beklagelig, konsekvens af denne udvikling er Klapps sociologiske tilgang, med sit fokus på de konkrete sociale funktioner, som kollektive forestillinger om helte, skurke og narre udfylder, i det store og hele blevet overset og ignoreret.

Dette er en skam. Klapps studie af helte- og skurke-opfattelsernes samfundsmæssige rolle og betydning rummer en mængde interessante overvejelser og distinktioner, som forekommer yderst relevante for forståelsen af en række nutidige fænomener. Dette illustreres glimrende i begge de to artikler, som vi har valgt at oversætte til dette nummer af SLAGMARK. Sine steder bærer Klapps analyser af, hvorledes helte- og skurkeskikkelser skabes og etableres, ganske vist præg af, at de er udformet for mere end 50 år siden. Det er således ikke sikkert, at alle umiddelbart kender de eksempler, som Klapp analyserer og bruger til at eksemplificere sine teser. Men de analytiske distinktioner Klapp introducerer, hans analyser af behovet for og brugen af helteskikkelser, og hans betragtninger over, hvordan politiske agitatorer og demagoger kan opbygge og udnytte en folkestemning, er lige så præcise og træffende i dag, som de var tilbage i 1950erne. Der er således ikke langt fra Klapps analyse af McCarthy-tidens skurkeskabelse til nutidens offentlige diskussion af, jagt på og undertiden hysteriske angst for terrorister og pædofile.

Så måske er tiden inde til at genopdage Klapp? Læs selv og bedøm.

\section{Litteratur}

Campbell, Joseph (1949): The Hero with a Thousand Faces, ${ }^{\text {st }}$ edition, New York: Bollinger Foundation.

Campbell, Joseph (1968): The Hero with a Thousand Faces, $2^{\text {nd }}$ revised edition, Princeton: Princeton University Press.

Klapp, Orrin E. (1948a): The Hero as a Social Type, ph.d.-afhandling (upubliceret), Chicago: University of Chicago.

Klapp, Orrin E. (1948b): "The Creation of Popular Heroes", Journal of Socio$\log y$, vol. 54, nr. 2, s. 135-141.

Klapp, Orrin E. (1949a): "The Folk Hero", Journal of American Folklore, vol. 62 , nr. 243 , s. $17-25$. 
Klapp, Orrin E. (1949b): "Hero Worship in America", American Sociological Review, vol. 14, nr. 1, s. 53-62.

Klapp, Orrin E. (1949c): "The Fool as a Social Type”, Journal of Sociology, vol. 55 , nr. 2, s. 157-162.

Klapp, Orrin E. (1954a): "Heroes, Villains and Fools, as Agents of Social Control", American Sociological Review, vol. 19, nr. 1, s. 56-62.

Klapp, Orrin E. (1954b): "The Clever Hero", The Journal of American Folklore, vol. 67 , nr. 263, s. 21-34.

Klapp, Orrin E. (1956): "American Villain-Types", American Sociological review, vol. 21, nr. 3, s. 337-340.

Klapp, Orrin E. (1959): "Notes toward the Study of Vilification as a Social Process", The Pacific Sociological Review, Vol. 2, nr. 2, s. 71-76.

Klapp, Orrin E. (1962): Heroes, Villains and Fools: The Changing American Character, Englewood Cliffs: Prentice-Hall Inc.

Klapp, Orrin E. (1964): Symbolic Leaders: Public Dramas and Public Men, Chicago: Chicago Aldine Publishing.

Klapp, Orrin E. (1971): Social Types: Process, Structure and Ethos. Collected Studies, San Diego: Aegis Publishing Company.

Klapp, Orrin E. (1973): Models of social order: an introduction to sociological theory, Palo Alto: National Press Books.

Klapp, Orrin E. (1978): Opening and closing: Strategies of Information Adaptation in Society, Cambridge; Cambridge University Press.

Klapp, Orrin E. (1986): Overload and Boredom: Essays on the Quality of Life in the Information Society, New York: Greenwood Press.

Klapp, Orrin E. (2006): Symbolic Leaders: Public Dramas and Public Men, Edison: Aldine Transaction. 
